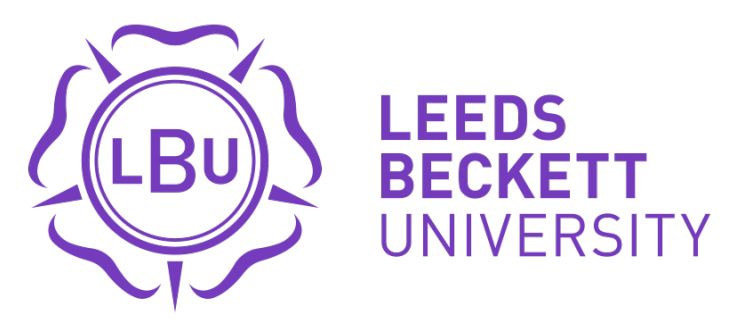

Citation:

Porpora, DV and Morgan, J (2020) American sociology, realism, structure and truth : an interview with Douglas V. Porpora. Journal of Critical Realism. pp. 1-23. ISSN 1476-7430 DOI: https://doi.org/10.1080/14767430.2020.1782708

Link to Leeds Beckett Repository record:

https://eprints.leedsbeckett.ac.uk/id/eprint/6909/

Document Version:

Article (Accepted Version)

The aim of the Leeds Beckett Repository is to provide open access to our research, as required by funder policies and permitted by publishers and copyright law.

The Leeds Beckett repository holds a wide range of publications, each of which has been checked for copyright and the relevant embargo period has been applied by the Research Services team.

We operate on a standard take-down policy. If you are the author or publisher of an output and you would like it removed from the repository, please contact us and we will investigate on a case-by-case basis.

Each thesis in the repository has been cleared where necessary by the author for third party copyright. If you would like a thesis to be removed from the repository or believe there is an issue with copyright, please contact us on openaccess@leedsbeckett.ac.uk and we will investigate on a case-by-case basis. 


\section{American sociology, realism, structure and truth: An interview with Douglas V. Porpora ${ }^{1}$}

\section{Douglas V. Porpora and Jamie Morgan}

Abstract: In this wide-ranging interview Professor Douglas V. Porpora discusses a number of issues. First, how he became a Critical Realist through his early work on the concept of structure. Second, drawing on his Reconstructing Sociology, his take on the current state of American sociology. This leads to discussion of the broader range of his work as part of Margaret Archer's various Centre for Social Ontology projects, and on moral-macro reasoning and the concept of truth in political discourse.

Key words: Douglas V. Porpora, critical realism, structure, artificial intelligence, death of democracy, Trump.

Douglas V. Porpora is Professor of Sociology in the Department of Communication, Drexel University, Philadelphia. In 2011 he and Dr Alex Gillespie (from the London School of Economics) took over the editorship of Journal for the Theory of Social Behaviour (JTSB) from Professor Charles W. Smith (the well-known economic sociologist). JTSB was founded by Rom Harré (Roy Bhaskar's thesis supervisor, who was, in turn, supervised by J. L. Austin) and Paul Secord in 1971, and along with Journal of Critical Realism, Philosophy of the Social Sciences, Cambridge Journal of Economics and British Journal of Sociology, JTSB has been a major forum for discussion of philosophical realism in the social sciences. Professor Porpora has over the years written numerous articles and commentaries and contributed to many debates published in JTSB (see Porpora 1983a, 1983b, 1983c, 1989a, 1989b, 1997, 2006, 2007a, 2016d, 2018). ${ }^{2}$ Professor Porpora has also been a long-time contributor to both the Journal of Critical Realism and its original incarnation as Alethia (see Porpora 2000a, 2000b, 2005, 2007b, 2009, 2016b, 2016c, 2017b, 2019c). As an enduring proponent of Critical Realism, he is perhaps best known for his early 'four concepts of structure' essay (Porpora 1989b; see also Porpora 1987, 1989a), which is reproduced in the landmark work Critical Realism: Essential Readings (Archer et al 1998). This introductory text of collected key works from early realists followed the establishment of the Centre for Critical Realism in $1996 .^{3}$ The subsequent realist-focused annual conference begun in 1997 was followed by the establishment of the International Association for Critical Realism (IACR) in 1998. Professor Porpora is a longstanding member of IACR's governing council and was elected President of the organization in $2019 .{ }^{4} \mathrm{He}$ is also a member of the Centre for Social Ontology (CSO), currently hosted by Grenoble Ecole de Management, directed by Professor Ismael Al-Amoudi and Professor Margaret Archer. ${ }^{5}$ His work features in all the volumes currently published as part of the CSO's Social Morphogenesis project (Porpora 2013b, 2014, 2015, 2016a, 2017a; Morgan 2016) and Future of the Human series (Porpora 2019a, 2019b; Carrigan et al 2020; Morgan 2019a). More broadly, he has contributed to numerous edited texts exploring aspects of realism (e.g. Porpora 2001b, 2004; Archer et al 2004) and since the 1980s his work has ranged across the social sciences taking in social theory, war, genocide, torture, and human rights, macro-moral reasoning in public sphere debate, moral and political communication and religion (e.g. Porpora 1980, 1982, 1993, 2011, 2013a; Porpora and Nikolaev 2007; Porpora et al 2010; Larson and Porpora 2011; Jenkins et al 2012; Mitman et al 2012). ${ }^{6}$ His books include

${ }^{1}$ Professor Jamie Morgan, j.a.morgan@ leedsbeckett.ac.uk

School of Economics, Analytics and International Business, Room-520 The Rose Bowl, Leeds Beckett University Business School, Portland Place, Leeds, LS1 3HB, Leeds Beckett University

${ }^{2}$ Including responses and engagements with Turner (1983), Lieber (1997), Elder-Vass (2007a), Lawson (2016a, 2016b); see also Porpora $(2017 \mathrm{c})$ on Lawson.

${ }^{3}$ Visit: https://centreforcriticalrealism.com

${ }^{4}$ Visit: http://criticalrealismblog.blogspot.com

${ }^{5}$ Visit: https://socialontology.org

${ }^{6}$ See also Porpora, Lim and Prommas $(1989,1992)$ 
The Concept of Social Structure (Porpora 1987), How Holocausts Happen (Porpora 1990), Landscapes of the Soul (Porpora 2001a), which was listed as one of the 'Year's Most Notable Books' by Christian Science Monitor in 2001, and Post-Ethical Society (Porpora et al 2013). A set of his essays Reconstructing Sociology (Porpora 2015), intended to introduce an American audience to Critical Realism, has also been published by Cambridge University Press and the book was joint recipient of the Cheryl Frank Memorial Prize in 2016.

After graduating with a degree in mathematics in 1974 and working for one year as a systems and statistical analyst-through the 1970s, Professor Porpora began his academic career as an instructor and visiting professorentered graduate school at Temple University and completed a PhD in sociology there in 1982. He has spent his entire academic career thereafter at Drexel University in his hometown and has been Professor since $1998 .^{7}$

The following interview with Professor Porpora was conducted by Professor Jamie Morgan for Journal of Critical Realism. ${ }^{8}$

Jamie Morgan (JM): How does a systems analyst with a degree in mathematics find themselves taking a PhD in sociology?

Douglas V. Porpora (DVP): Mathematics was a choice influenced by my parents. From an early age, I seemed to have an affinity for the conceptual precision of abstract mathematics and the logical deductions of its proofs. I wasn't particularly good at calculation, but that is different. I suck at arithmetic and have to think a lot to make change.

JM: You are not alone there, there is a long tradition of conceptual thinkers for whom applied calculation was a problem, though you often find that the two go hand-in-hand.

DVP: In any case, I already had an interest in philosophy and in religion, but as mathematics seemed more marketable than philosophy or theology, my parents pushed me in this direction as an undergraduate. When I graduated in the midst of a recession, Grumman Aerospace offered me a job as a systems analyst, helping to computerize control of their vast tool inventory. Ironically, I didn't get the job because of my math background, which meant I wasmade me among the few people then who knew something about computer programmings. It was rather, due to summers I spent working in factories (among them spot-welding in a clam rake factory), they figured correctly that I could get along well with workers on the shop floor. ${ }^{9}$

Systems analyst wasn't a job I really wanted. I have always been obsessed with philosophical concerns about determinism, moral relativism, and reductive naturalism. I guess I was influenced by lots of things, but I wasn't reading anything in particular that I can remember. In contrast, I have minimal concern about mathematical constructs or, certainly, issues related to corporate supply chains. I wanted to be a university professor. So, I immediately applied to $\mathrm{PhD}$ programs.

Ideally, I would have chosen a $\mathrm{PhD}$ in philosophy but considered that degree too risky. I thought a degree in sociology would at least leave me marketable for a non-academic job if I did not land a job as a university professor. Plus, I thought in sociology I could still draw on mathematics and philosophy. And, finally, at the time, I thought sociologists the main perpetrators of the philosophical positions I worried about. So, I thought I

\footnotetext{
${ }^{7}$ porporad@drexel.edu For information on and access to Porpora's work and related activity visit: https://drexel.edu/coas/faculty-research/faculty-directory/porpora-douglas/

${ }^{8}$ See also in this series Archer and Morgan (2020); Rescher and Morgan (2020).

${ }^{9}$ Note from Jamie: a clam rake is a tool used in tidal fishing.
} 
would enter their ranks to 'take them on'. They have not seemed to appreciate the gesture, hence Reconstructing Sociology all those years later.

JM: You say 'draw on mathematics and philosophy', but as you have commented before, the relative emphasis between these two and the specific foci of sociology have been more conducive to the former than the latter. This, of course, varies by country and tradition. How would you characterise American sociology in the 1970s and early 1980s?

DVP: I would describe American sociology in the 1970s and 1980s as generally empiricist and that was something I didn't want to do but did want to react against. As you know, to a philosopher, empiricism generally refers to work in the tradition of John Locke, David Hume or George Berkeley. It has many strands, and various subsequent lines of development after these early empiricists. But its core commitment is that (contrasted with rationalism) our knowledge ultimately derives from 'ideas' whose only source is sense experience. All kinds of issues can follow from this (based on scepticism etc.), but in American sociology, when I was starting out the main consequence was the one associated with Hume, a commitment to identification of observable events, which is an empirical commitment that effects the focus of investigation. This, of course, combines empiricism and positivism, and obviously, Hume wasn't the dominant acknowledged figure in sociology. Time moves on and so do recognized sources and resources. But influences linger. I would say the dominant approach in the field followed Emile Durkheim's Rules of Sociological Method, which directed sociologists to a 'pure' sociology of uncovering statistical relations among social facts. The main aim was to identify these 'social' facts and this left no room for the behaviour of people as individuals. This advice makes sense only if causality is understood in terms of nomothetic, 'if-then' type laws that ask nothing about the mechanisms involved in making things happen.

JM: Whilst I don't dispute your characterisation, after all, it resonates with the substantive claims made in the immanent critiques that form the basis of many early realist classics of the 1970s and 1980s (for example Bhaskar 1979, 2014; Keats and Urry 1975), it is still a little odd to see the period phrased so starkly as one antithetical to high theory and nuanced qualitative investigation, whilst preferring to focus on statistical social facts (around 80 years after Durkheim). There is still a tendency to imbue the 1970s with romanticised notions of radical sociology in the context of global economic and political crisis (Vietnam, oil shocks, the end of exchange rate controls, stagflation etc.), and following on from social movements that began in the $1960 \mathrm{~s}$, in which organising within higher education institutions played a leading role (students reading Herbert Marcuse's One-Dimensional Man, the Committee of Concerned Asian Scholars in the USA, the influence of Stuart Hall and others and the New Left Review in the UK).

DVP: Well, it is very interesting you say this, and you have a point. I entered graduate school in 1975, during what turned out to be a very momentary florescence of Marxism in the academy, to which I then converted. So, there was considerable push-back from a number of directions to the stark empiricist, positivist hegemony I described. There were Frankfurt school figures like Eric Fromm and Herbert Marcuse and in addition, even outside of the Marxian ambit, symbolic interactionists who contested sociology's over-quantification. But the florescence of Marxism did not last long and did not dominate. By the end of the 1970s, it was already being eclipsed by post-structuralism, which took radicalism in a new direction and spoke to the new politics of identity, and this still overshadows movements of a more political economic nature today. But as the dust settles, what stands clearly before us in American sociology, stronger than ever and now also influencing the UK, is the continued hegemony of empiricism. Even now, whenever provocative conceptual debates break out, it is interesting to observe how soon are the calls to move beyond these 'sterile debates' and get back to work.

JM: Perhaps we might come back to post-structuralism's influence on the 'culture wars' later. In retrospect then, the kind of issues that caught your attention predisposed you to an interest in Critical Realism? An approach that 
was sceptical regarding law-like relations that create false expectations of the scope and potentials of sociology and social science?

DVP: Yes, this was the target of one of my first articles, 'On the Prospects for a Nomothetic Theory of Social Structure' (Porpora 1983b). I had sent it to the Journal for the Theory of Social Behaviour (JTSB). Unbeknownst to me, the journal founders were either realists or sympathetic to it. The journal decided to do a special issue on my article with replies from both positivist critics (e.g. Turner 1983) and one Critical Realist in political science, Jeffrey Isaacs. The editors advised me in advance of my responses (Porpora 1983c) to examine Rom Harré and Edward Madden's Causal Powers and Roy Bhaskar's A Realist Theory of Science. After doing so, I concluded I was a Critical Realist, but did not connect with the original British crowd that became IACR until 1998 when I attended its second annual meeting. It is a long time ago, and a bit hazy, but my 1998 paper on regression was the first time I actually wrote as a Critical Realist (see Porpora 2001b; Olsen and Morgan 2005).

JM: But still, significantly more than a decade after you started thinking along realist lines, that is quite some time for ideas to be percolating. Serendipity then? Though I expect there was not much chance that a 'Sliding Doors' moment would have led to you becoming a post-structuralist. Did the focus of your nomothetic paper mesh with other work you were undertaking at the time, your essays on teleology, materialism and postWittgenstein perspectives on action (Porpora 1980, 1982, 1983a)?

DVP: Yes, serendipity, and no, there would have been no chance whatsoever of my becoming a poststructuralist. I had been a Critical Realist before I knew that Critical Realism existed. That article, along with the one you mention on the post-Wittgensteinians, also published by JTSB, became chapters in my dissertation and eventual first book, The Concept of Social Structure (Porpora 1987). I do, by the way, remember the movie Sliding Doors.

JM: So, what was it you were saying regarding post-Wittgensteinians and how did this inform your perspective on structure?

DVP: The post-Wittgensteinian philosophers made a distinction between reasons and causes because they thought of causes in a nomothetic way, which does not accord with how we explain ourselves in terms of reasons. So, anthropologists like Clifford Geertz and sociologists as well were arguing that social explanation is not a species of causal explanation, but more an enterprise of interpretive understanding. This view creates a gulf between law-like natural causes and reasoned human behaviour.

JM: A position, of course, which misrepresents both nature and society. But still, this is an old dichotomy that has exercised philosophers in terms of a family of related conceptual dividing lines: nature and society, determinism and free will, facts and values etc. It often strikes me that many of those who developed or adopted realist positions in the 1970s and 1980s were influenced by Marx or Marxism, and this predisposed them to work through these dichotomies looking for a new language of argumentation (which for realists would be depth realism, stratification and emergence, enabling a causally contextualised 'free' human to be conceptualised based on exercise of distinct powers, within a social reality framework of agency and structure). For example, Andrew Collier was working through these kinds of things in his essays in John Mepham and D-H Ruben's classic edited text series Issues in Marxist Philosophy at the beginning of the 1980s and in his Socialist Reasoning (Collier 1990). And, of course, reasons as causes loom large in his introduction to Bhaskar's work Critical Realism (Collier 1994: 118-120). One might also think of many of the early contributors to the journal Radical Philosophy and, of course, the work of Alex Callinicos, Bob Jessop or (if we extend the radical political economy theme) Andrew Sayer. 
DVP: Okay. Yes, that is interesting. Generally, this view of causes and laws, was a problem, and yes anyone interested in Marx would want to think about that. If causality involves laws, then affirming the kind of objectively 'hard' or mind-independent structures we associate with Marx - class relations, competition, even power differentials - becomes structurally reductionist, because these drag human action away from pure reasons back to the deterministic realm of causality. But once we dispense with the nomothetic covering law model of causality, that problem disappears. So, I was following philosopher Donald Davidson in arguing that with a different understanding of causation, reasons too could be causes. ${ }^{10}$ Bhaskar was thinking along those lines as well, although I did not know it at the time. Because I was interested in reasons as causes, one of my favourite professors at that time, very influential in my conversion to Marxism, would always refer to me as a cryptoidealist. Ironically, although my ideas stayed the same, with the eventual cultural turn, I would find myself decried by others as a structural reductionist.

JM: Yes, misunderstanding of work that tries to address long-held dichotomies is often criticised by attributing it to one or the other of the positions it seeks to mutually transcend. This, as you say, is ironic, especially when one thinks that realist philosophy and social theory typically adopts immanent critique - and so explores its targeted positions and categories with the explicit or stated aim of being neither of some given binary; a point that tends to indicate that counter-criticism, which oscillates between idealist and reductionist (structural determinist) claims follows from critics not reading what they are claiming to be criticising. It strikes me, however, that your classic early essay, 'Four concepts of social structure' (Porpora 1989b; Archer et al 1998: 339-355) is not quite immanent critique. It is categorical clarification in order to advocate one of the four concepts. You take four concepts of structure:

1. Structure as pattern of stable aggregate behaviour.

2. Structure as law-like regularity governing behaviour of social facts.

3. Structure as systems of human relationships among social positions.

4. Structure as collective rules and resources that condition behaviour.

And dispense with three of them: stable patterns reduce structure to an epiphenomenon, law-like regularities are rare, do not persist and direct attention away from how they are grounded, and collective rules, following Anthony Giddens, are essentially a cultural rather than structural concept. This leaves structure as social relationships, which you claim is the most tenable, but only if placed in the context of a 'post-positivist' 'realist' conception of causes, tendencies, capabilities and properties, which can allow for human agency. So, whilst the essay itself is perhaps not quite immanent critique, it is stated as a kind of attribution of authority for immanent critique, drawing on various Marxist-influenced realist philosophers, including Bhaskar, to suggest structure as social relationships is 'not a version of sociological holism. It does not portray social structure as something that operates over the heads of human actors. Instead, social structure is a nexus of connections among them, causally affecting their actions and in turn causally affected by them' (Archer et al 1998: 344). Would you say this builds from the position you also develop in your thesis and its published form, The Concept of Social Structure, and have you changed your mind about any aspect of the way you conceptualise the issues since these early works?

DVP: What you say is why I feel so at home with Critical Realists. You articulate precisely what I have tried to convey in that 'Four concepts' piece, in The Concept of Social Structure, and other writings. It is a theme that has endured since my graduate school days. A materialist understanding of social structure as positional relations, focused on 'structures' that might exist and exist consequentially even without our awareness. This

${ }^{10}$ Note from Jamie: Doug is referring to Donald Davidson's classic 1963 paper 'Actions, Reasons and Causes', which contests the position attributed to Wittgenstein that reasons cannot be causes. Donaldson (1917-2003) was Professor of philosophy at University of California Berkeley and worked mainly on action, epistemology, truth and mind. He ranks with W. V. Quine in the twentieth century canon and was influenced by A. N. Whitehead. There is an excellent essay on Donaldson in the Stanford Encyclopedia of Philosophy: https://plato.stanford.edu/entries/davidson/\#toc 
view, despite its attractive characteristics when we pose basic questions about social reality, has not much caught on in American şociology. This remains surprising because as I observe in Reconstructing Sociology, this same understanding of social structure is affirmed not just by Marx but also by Pierre Bourdieu, who has currently captured the imagination of American sociology. However, as I set out in Chapter Four of Reconstructing Sociology, there is an 'Americanized Bourdieu' focused on cultural capital and habitus and stripped of the rest - which is not to say I endorse everything about the rest, just that social structure in American sociology is either ignored or completely subjectivized.

And yes, of course, I have refined some of what I suggested early on. This too is set out in Reconstructing Sociology:

Today, however the terms of debate are a bit different. New actors have entered the scene [and] After 20 years, I have introduced some refinements. Twenty years ago, I defined the CR conception of social structure as systems of relations among social positions. That statement, however is a bit too narrow. First, the word system may be too restrictive [...] a society's social structure need not be a system in any strong sense. Its structure is the totality of social relations [...] Second, the relations at issue are not exclusively relations among social positions but also relations of those positions to social constructs like resources [...] Finally, today I have added parenthetically the adjective material to the ontological objectivity of the social structural relations CR emphasizes [on the basis that, following Margaret Archer, culture can be defined separately]. (Porpora 2016e: 97-98)

It is amazing to me how little American sociologists think about the reality of structure, structure as an ontological category. This does not make them entirely methodological individualists. Like Anthony Giddens, they will allow cultural phenomena that exceed individuals. But they work from conflations and seem resolutely nominalist about positional relationality. For example, they talk endlessly about power, even 'power over', without seeming to realize that ontologically, power or at least power differentials are relations rather than behavioural transactions or discourse.

What I further find dismaying is that even when people follow my work, when they do try to capture what I am saying, they frequently do not. They do not say what you just said. They translate what I say into some kind of transaction or interaction. But, a relation like power is not an interaction or a transaction. It is, rather, a state of affairs that shapes ensuing interactions or transactions. So, it is not so much that the majority of American sociologists actually disagree with me as that they seem unable even to grasp what I am saying. As with any minority position, the weight of the majority sometimes makes me feel like I am the crazy one, which is why I find it reassuring that you are interpreting me correctly.

JM: Well, in terms of power, perhaps it is that something like Steven Lukes' multi-dimensional conceptualisation never really took hold in the USA, and so there has been no appropriate framework in which to make sense of what it is that you have been trying to convey? For Lukes (1974), power can be parsed into: 1 . Agent A makes agent B do something they would not otherwise do by the mobilization of some resource, skill or capacity (a direct behavioural concept of power via threat, coercion, violence, persuasion, material inducement etc.) 2. The knowing manipulation or construction of structuring contexts of activity to the benefit of some and not others (a more structural concept of power) 3 . The fundamental socialisation of time and place that affects everyone as a 'worldview', which may cause real and perceived interests to diverge (a meta-structural concept of power). It strikes me that this is quite a different way of parsing the pervasiveness of power than the more amorphous conceptualisations that have taken root in American sociology over the last thirty years (capillary power and so forth). 'Power is everywhere and in everything', may be trivially true but can be analytically unhelpful as a blanket proposition. Arguably, Lukes set of distinctions allows for a nuanced conception of power, 
and arguably realists have proceeded to provide an ontology of this. ${ }^{11}$ For example, a focus on (rather than reduction to) structural relational concepts of power, which in turn enables a distinction between different powers or capacities of entities and the potentials that inhere because of capacities (something that is, it seems, important within Critical Realism; Bhaskar, for example, categorises this in terms of Power 1 and Power 2 ; others explore the powers of generative mechanisms and so on, see Morgan 2007: 372-373). But, your point seems more general than your example. Your suggestion seems to be that American sociology has a sociology of knowledge and has developed and reproduced itself in problematic ways. Addressing this problematic situation seems to be why you wrote Reconstructing Sociology and also forms much of the initial subject matter of what you wrote. In your 'Seven myths of American sociology' essay that introduces Reconstructing Sociology you state (Porpora 2016e: 2-3):

[W] sociologists urge others to examine their presuppositions. We call this activity critical thinking, and when accrediting agencies come by to ask us what we do and what value we offer society, it is the development of critical thinking we often tell them we provide... [But in] the main we rather repress critical reflection on sociology. It is a feature that distinguishes American sociology from, say British. Think of the status that theory holds as a sub-discipline within American sociology. It is not one of the areas for which one seems many calls in the employment bulletin... [And] students are urged to leave behind the big questions that divide the paradigms and settle on some concrete, empirical project within one. [Furthermore, there are a number of presuppositions] that themselves generally go unquestioned in sociology. Coming from those so insistent on critical thought the twin 'supposeds' are particularly ironic.

Could you elaborate on what those 'twin 'supposeds" are?

DVP: Well, first let me say that Lukes articulates a pre-Foucauldian conception of power that I continue to endorse. Foucault has perhaps identified a different form of power that is also important, but that does not mean that what Lukes identified is wrong or no longer around. It is reflective of academic fashion, however, that Foucault is where the action is, and Lukes is more or less forgotten.

But, you ask about the 'twin supposeds' in my text. I have to say that looking back at it, I am not at my clearest here. I think the twin supposeds to which I was referring were the problematic tendency of sociologists to devote activity exclusively to 'normal science' and, following from this, to avoid questioning paradigmatic or disciplinary presuppositions. I was referring to these supposeds as 'twin' because they amount to the same thing: Not questioning underlying presuppositions, so that one just operates within the prevailing parameters or rules of the game. Again, this is not new. In my graduate days, one of our leading faculty members observed of me that if I went ahead with a theoretical dissertation (violating the 'rules'), I would end up driving a cab. Given the nature of American sociology, he actually had a point. I just got lucky.

My point though is that questioning presuppositions involves conceptual rather than exclusively empirical thought. It calls for work on metaphysics, ontology or whatever. But this is considered beyond the bounds of science. I call this dual prescription ironic because sociologists $d o$ call on others to step back from and examine the cultural parameters in which they operate. So, tacitly we have higher and different expectations of others: do as we say, not as we do.

\footnotetext{
${ }^{11}$ Note from Jamie: Anthony Giddens was the general editor of the series in which Lukes' classic work was published. Note also, that the first realist works on powers and capabilities of entities (leading to the concept of stratification and emergence) predates Lukes' work on what is essentially the sociology (political economy) of power. For different takes on meta-issues of realism see also Lau and Morgan (2014)
} 
JM: And yet, most social scientists would not recognize the relevance of the statement, since it contradicts the self-image of science as they have been socialised to perceive it. Within the socialisation, quantification and testing are the very basis of adequate knowledge, based on data, method and empirical claim. If we think of this as sociology of knowledge consequences, empiricist and positivist social science come to command the language of objectivity and science. Once this is so, the very terms of debate implicitly become minor deviations from empiricism and positivism as points of departure, the very foci of critique narrows and becomes self-referential. Others, meanwhile are immediately positioned outside of reasonable discourse. They are varieties of 'radical', doing something different (which is 'not for us'). They are somehow anti-science, lacking in objectivity, dubious in method etc. Critical Realism, of course, suffers from both sides in this situation: it provides fundamental critique of how science and social science are conceived by some practitioners, but simultaneously rejects some of the more extreme consequences of doing so in terms of relativisms and so forth. Reclaiming objectivity and science, reasserting the possibility of adequate truth claims and constructively articulating critique for a better world is, seemingly a thankless task. That task, however, seems to be the connecting thread of your 'Seven Myths'. It might be useful if you briefly itemise and contextualise them.

DVP: Wow. Okay. Well, Myth One is that ethnography is second-class science, merely 'exploratory' as it deals with only one case, and if science means identifying causes and causes require general laws, then focusing on a single case does not get us far - we need to generalize to a population. Hence the privileged status of quantitative research. But, the reasoning here is falsely premised, since events or outcomes (conflated with laws) require explanation, so if we look beyond 'laws' and move to mechanisms, then the generality of a cause becomes a question separate from its mere existence. Much of science, not just social science, is concerned with descriptive accounts of mechanisms - the double helix, the structure of an atom, natural selection. On a causal powers account, ethnographic description of mechanisms assumes greater importance (with the implication that more resources should be directed to ethnography within sociology).

Myth Two is that the appropriate posture in 'good science' is value neutrality. I essentially argue that what good science requires is intellectual honesty and adequate truth claims rather than neutrality, especially as neutrality is itself a value position that is not necessarily neutral. Imagine staying neutral on the Holocaust. There is the problem of false equivalence.

JM: Yes, an issue that begins with misinterpretation and misappropriation of Hume's 'Guillotine' (Hume 1962: 177-178):

In every system of morality which I have hitherto met with... the author proceeds for some time in the ordinary way of reasoning... when all of a sudden I am surprised to find that, instead of the usual copulation of propositions, is and is not, I meet with no proposition that is not connected with an ought, or an ought not. This change is imperceptible; but is, however, of the last consequence. For as this ought or ought not, expresses some new relation or affirmation, it is necessary that it should be observed and explained; and at the same time, that a reason should be given, for what seems altogether inconceivable, how this new relation can be a deduction from others, which are entirely different from it

A statement that becomes in A. J. Ayer's classic logical positivist and deflationary framework: 'exhortations of moral virtue... do not belong to any branch of philosophy or science' (Ayer 1983: 137). As you say, a 'false equivalence' underpins this, since Hume is not quite right to assert the statements are different because unrelated. ${ }^{12}$ Your Holocaust example invokes the well-known adequacy of descriptive language response to value conditions in formative language, invoking different contexts of explanatory relevance. In stating Myth

\footnotetext{
${ }^{12}$ See Searle's classic refutation (1964) and Morgan (2005).
} 
Two (Porpora 2016e: 14), you reference Roy Bhaskar, and there are several versions of the example he borrows from Isaiah Berlin, regarding the fate of Jews and others, So, in Germany under Nazi rule (e.g. Bhaskar 1994: 110):

a. The country was depopulated.

b. Millions of people died.

c. Millions of people were killed.

d. Millions of people were murdered.

All are true, but the more accurate is also the more evaluative, and has quite different implications for the link between explanation and subsequent moral prescription, by way of a circumscribed ethical naturalism.

DVP: Yes, as I think I also say, Dante reserved the gates of Hell for those who try to remain neutral during conflicts of a moral nature. This leads also to Myth Three, that everything is 'socially constructed' and nothing about what we construct is significantly rooted in any ontologically independent reality, that truth is relative. I think for a Critical Realist readership there is no need to rehearse the arguments against this position.

JM: Perhaps not, but it is important that other readers do not infer more than you are implying. If we recall your statement that 'Foucault has perhaps identified a different form of power that is important' and note that in sociology of knowledge there is a difference between authorial intent and consequence, it is probably worth briefly noting that many realists recognize some value in the insights of those who ultimately end up with what realists argue are untenable positions. For example, the well-known realist philosopher Christopher Norris states in the conclusion to his classic work on Jacques Derrida, 'Derrida's scepticism is not what some of his interpreters would make of it, a passport to limitless games of their own happy devising' (Norris 1991: 27).

DVP: Which in many ways serves to confirm the importance of addressing Myth Four (beginning from an underlabouring perspective). Myth Four is that the most important questions are empirical rather than conceptual. A lot of what we have just been saying addresses this myth. In Reconstructing Sociology, I point out that Durkheim commits two conceptual errors in Suicide. First, he defines suicide in a way that, dispensing with intentionality, departs utterly from the common sense definition, so that he is really studying something other than what we mean by suicide. I suggest calling it 'Durkicide'. But his second error is to operationalize suicide by using official statistics, which, fortunately counts suicide as we ordinarily understand it and not Durkicide. So, in Durkheim's case, his second error cancels out the first, preserving his work from nonsense.

JM: But, in broader context the point is to suggest conceptual coherence is important? And conceptual critique, with a view to more consistent theorisation beginning from ontology, can lead to more adequate empirical investigation?

DVP: Well, following from that, if we think of the myths as linked, Myth Five brings us back to your reference to 'untenable positions': sociology can and should dispense with the Cartesian cogito. This is how poststructuralists commonly and disparagingly refer to human selfhood, whilst positivist sociologists tend to compose human selfhood as though it were a site where values of different variables are instantiated (a kind of actualism in relation to human ontology). Descartes, of course, is not the best guide to the nature of human selfhood (and is commonly criticised for inadequate accounts and consequences for embodiment etc.) but the thinking self is nonetheless a crucial concept.

JM: There is certainly something odd about disembodied rationality as a default. 
DVP: But equally something odd about some approaches that might seem to fill this gap. Myth Six addresses the problematic consequences of a sweeping 'turn to practice'. Reducing everything to practice tends to do away with structures, agents and culture. The turn leads to a focus on the actual in the name of the empirical. Older readers will recall that this move originates with Giddens, but while Giddens is largely gone as a force in sociology, the 'turn' remains very much alive.

Myth Seven is the other side of the coin, a tendency for Critical Realism to overreact to positivism and identify Critical Realist methods exclusively with qualitative methods. In discussing Myth Seven, I essentially reprise the defence of analytical statistics to which others, like Petter Naess, Wendy Olsen and you have contributed. This is still an issue that divides Critical Realists, especially in economics with its overwhelming focus of resources on modelling and testing datasets, though maybe less so among other Critical Realists.

JM: So, discussion of these 'Myths' cumulatively amounts to a critique of the state of the field in American sociology. But, in keeping with an 'under-labouring' theme typical of Critical Realists, Reconstructing Sociology also amounts to a constructive manifesto for a project of improved (progressive) social science. You are, of course, not alone in drawing attention to the problems of the field and in identifying ways forward. Phil Gorski at Yale University, Christian Smith at University of Notre Dame and Ruth Groff at Saint Louis University are fellow travellers. ${ }^{13}$ All four of you (and probably others I am unaware of) have been working on these kinds of ideas for quite some time now. Would you say progress has been made?

DVP: Yes, there has been a team of us. Some of the work followed for quite a few years from a Templeton grant awarded to make an impact on American sociology. This was led first by Chris Smith, then by Phil, and also included Ruth, George Steinmetz, Tim Rutzou and Laura Donnelly. And we had an effect on many graduate students across American universities and also faculty at an early stage in their careers. Critical Realism is now something definitely known about in American sociology, but it is still not mainstream and there is still push-back against the kind of conceptual, theoretical thinking that Critical Realism advocates (beginning with the recognition that 'every approach has at least an implicit ontology, so it is important to make this explicit, consistent, coherent' etc.). Given the current drivers of the field, I do not expect the overall character of American sociology to change soon.

JM: Since the underlying theme in Reconstructing Sociology is that adequate ontology leads to better social theory, which in turn makes for better empirical work, it seems worth asking: to what degree has your work in social theory informed your more empirical work. For example, with the Berlin-Bhaskar reference in mind, How Holocausts Happen (Porpora 1990)?

DVP: Well, How Holocausts Happen (Porpora 1990) was less original empirical research than a polemic against U.S. foreign policy and a first foray into what I have gone on to call 'macro-morality'. More relevant to your question would be the work that went into Post-Ethical Society (Porpora et al 2013). This was an empirical investigation of the way the American public sphere debated the attack on Iraq and the subsequent revelations of torture at Abu Ghraib.

JM: This seems to be the kind of work (subject/format/publishable prospects) that meet your academic obligations - the 'professional expectations' of what a professor does in a Department of Communication. Given that it would be a 'theory-practice inconsistency' to critique American sociology and make the case for reconstruction and then not demonstrate this had influenced your own applied work, in what sense is Post Ethical Society informed by your general Critical Realist framework (the 'how the world works' built into ontological inquiry/awareness)?

${ }^{13}$ For example, Gorski (2013), Smith (2016), Groff (2004). 
DVP: Mainly informed by my awareness rather than programmatically and explicitly stated as 'Critical Realism' throughout. WhileWhile in Post-Ethical Society I do not 'highlight' Critical Realism, my take on Critical Realism definitely underlies the research strategy. Specifically, that work relied on both quantitative and qualitative analysis. The quantitative analysis - not regression but 'Analysis of Variance' (ANOVAs) - was not a search for 'general laws'. It was a way of showing that in the case at hand there was a difference substantially beyond 'chance' between how the secular and religious media debated the issue. The secular media blunted the moral aspects of the debate. That systematic difference was a matter of comparative counts and hence was quantitative. The way in which the secular media blunted the moral aspect -the rhetorical mechanisms if you will - is a qualitative question. So, since it is a basic tenet of Critical Realism that methods should be appropriate to the object of inquiry and to the facet of it under investigation (see also Porpora 2016c), my team and I used qualitative discourse analysis to analyse thathe how. ${ }^{14}$ And here, let me say, that unlike a lot of discourse analysis, which is pressured to ape quantitative analysis, we employed a very non-formulaic, more literary, more context-sensitive, close read of the material. So in short, on the one hand, we did not eschew quantitative analysis but on the other hand, when we did qualitative analysis, we did it without apology or tilt in a quantitative direction. And finally, let me say, I think this kind of 'mixed method' approach (which, as you know, Wendy Olsen has also done a great deal to develop in the UK) is very effective. ${ }^{15}$ The quantitative part providing a kind of analytical skeleton and the qualitative the flesh.

JM: As anyone who knows you is aware, your research interest in secular and religious media has some further context. Religion matters to you both professionally and privately, but so do truth claims. For many social scientists, including many proponents of Critical Realism, this is an odd and awkward combination. How do you equate the two?

DVP: Ah, good question, Jamie. Of course, you know me well. Yes, a common assumption seems to be that there are no good reasons to hold religious beliefs and so anyone who is religious must hold such beliefs irrationally. As you know, Maggie Archer, Andrew Collier, and I wrote a book countering this view (Archer et al 2004). Actually, Roy Bhaskar was originally on this project with us and certainly continued to agree with that point, although he ultimately decided to write on this theme on his own.

JM: Yes, his work on spirituality eventually went in a slightly different direction (Hartwig and Morgan 2014). There are, however, many others who are religiously inclined or interested in the influence of religion that find Critical Realism conducive to their concerns, Mathew Wilkinson, Brad Shipway, Andrew Wright etc. (Morgan 2015).

DVP: For me, the issue is how one addresses the 'evidence' and what evidence 'is' for this very special case. It is not all about miracles or revelation, there is a 'turning to'. I think that there is a category of people who are religious because they experience what they consider a greater ontological reality in their lives, while people who are not religious either experience no such thing or interpret it differently. The question then becomes, whose experience is right? My own view is that unless there is overwhelming evidence against it, it is rational for people to trust their personal experience. It is a kind of qualified standpoint epistemology that still holds a place for judgmental rationality. So, if you feel you have no experience of a greater reality, I think there is no compelling reason to believe in such. But those of us who think we experience such reality on the contrary have good reasons to trust that experience.

${ }^{14}$ Note from Jamie: this alignment of methods and subject/object of investigation is something, for example, Danermark et al. (2019), concisely make the case for, as does Andrew Sayer (1992), though he is less enthusiastic regarding steps beyond descriptive statistics.

${ }^{15}$ Note from Jamie: see, for example, Olsen $(2019,2012)$
Formatted: Font: Italic 
JM: This seems a special case of trust compared to our received concept though (see Colledge et al 2014), but I take the point from your collective work with Margaret Archer and Andrew Collier (Archer et al 2004) that there either is or is not a God and that is ultimately an ontological issue (and not in Anselm's sense of argumentation). And whilst there is a basic plausibility in your further experiential claim (since it helps to make sense of why so many have and continue to be religious without only considering them over-socialised theological dupes) this does lead to some old dilemmas in theology doesn't it? Are we all capable of this 'experience' of the divine? If not why would a benevolent interventionist God make only some of us attuned to the divine (capable of being in 'Grace'?). Problems of the 'elect' then might follow. By contrast, if we can all, in principle, experience the divine, but not all have been placed in a position to do so, then how are those who never received the appropriate socialisation 'judged' later, if this is not 'all there is' (a variant on the problem all monotheistic religions encounter)?

DVP: Well, first let me say I don't believe in all that Grace stuff. I don't believe anyone is going to be 'judged' for epistemological mistakes. And I actually don't think God is omnipotent. Instead, as per process theology or the Kabbalah, I think God struggles. But I think your question remains: Why do some share my experience and others not? I don't think God decided to privilege me and not you. I do think that while I do not have a musical ear, I do have a religious ear. I resonate with the divine that comes through in all the different religions.

But then again, I don't think it all comes down to different experiences. While there are reasons to doubt that any greater or deeper reality exists, there are also grounds that are purely publicly accessible for believing affirmatively that I find that non-religious people just dismiss. Why is there 'something' rather than 'nothing'? And why this particular 'something', this universe that as physicists acknowledge, is so 'fine-tuned' as to make intelligent life even possible? That there is some larger meaning to our existence, that our existence is not just a fortunate outcome of blind physical principles, does not seem unreasonable to me. Nor does it seem to me unreasonable to think that moral principles like love and justice need to be grounded in some affirmation of their transcendental status. Otherwise they become mere preference or at most collective prudence (see also Porpora 2006).

JM: The pragmatist Nicholas Rescher makes some parallel arguments regarding 'something' and 'nothing' ('axiogenesis') and whilst there is always a counter-argument or scope for scepticism where fundamental claims are made, there is also something important about addressing such fundamental concerns. As he suggests, it is an impoverished profession of philosophy that turns its back on issues that are so important to people - merely because they are speculative - one can still be systematic and transparently apply the traditional tools of philosophical analysis and argument (Morgan 2019b).

DVP: Yes. Rescher is still on my reading list, but from a Critical Realist perspective, who polices the boundaries and what would that mean? Who is being less true to the principles of Critical Realism? Religious people who look for answers to such questions (and so look for ways to reason about belief) or the non-religious who think the questions require no answer (which can become just assertion)?

JM: As an atheist, there seems a significant conceptual and attitudinal distance between your reasoned conditional belief and the more dubious angry righteousness of some of the Christian right. The tendency to conflate the two probably both worries and irritates you. At the same time, you have, in theory terms at least, Marxist sympathies and are a Catholic and institutionally (the latest Pope notwithstanding) I expect that has pulled you in different directions at times. Overall though is your religious inclination why you have a longstanding working relationship with Margaret Archer?

DVP: I suppose the Catholicism Maggie and I hold in common is one bond between us, but apart from the 2004 
book, it rarely surfaces in our work together. More important to our working relation is our common view of social theory. Both of us were early critics of what was once the theoretical hegemony in sociology of the views of Anthony Giddens (and that goes back to my early work on structure, as we discussed earlier). Although Maggie and I do have our differences, they are rare. We have worked so long together because we have shared a distinct view of things.

JM: It might be said that your work seems to have more affinity than say David Elder Vass's (though the point is arguable, Archer and Elder-Vass 2012; Elder-Vass 2007a, 2007b; Porpora 2007a; Morgan 2014) and you are one of several who have contributed to every volume of Archer's Centre for Social Ontology (CSO) project series of edited texts, both the Morphogenic Society project and the more recent Future of the Human project, which I have been more involved in (Porpora 2013b, 2014, 2015, 2016a, 2017a, 2019a, 2019b). ${ }^{16}$ I do not want to trivialise this, since the project is a serious endeavour (Archer and Morgan 2020), but you also share with Archer a keen interest in science fiction novels; has this influenced the work you have done in the series?

DVP: Oh yes, and I share that interest with you as well. I do read things other than science fiction. I am, for example, a big Jane Austen fan. Generally, though, I read fiction at night to turn my mind off from detailed analysis. What I am most frequently looking for is escape. But science fiction, certainly the best of it, provides more than escape. It wrestles with political and moral issues that are on the horizon. So you allude to the work of the Centre for Social Ontology, which has been questioning lately what it means to be human or the moral equivalent of human. And certainly, science fiction from Blade Runner to Westworld, even Star Trek, has had a lot to say on this topic. What fiction can do, arguably sometimes even better than scientific ethnography, is touch our emotions in such a way as to alter how we think about things. And certainly, science fiction has informed, among other things, what I think it means to be a person.

JM: An issue that looms large in your and Archer's essays in the Future of the Human series, though the formal point of departure is as much social science and philosophy as it is science fiction: Chris Smith and Lynne Rudder Baker's concepts of a person, Andrew Collier on Being and Worth (Collier 2005), and the various arguments from Nick Boström regarding Transhumanism, as well as 'superintelligence'. Clearly, science fiction can sometimes carve out futures that subsequently turn to fact. That said, even the most astonishing and wildly imaginative science fiction can betray its origins in time and place. Cixin Liu's 'Remembrance of Earth's Past' trilogy (beginning with his Three Body Problem), for example. The idea that one might weaponize the laws of physics is brilliant, but his picture of a universe whose 'cosmic sociology' conforms to a 'political realist' aggressive survivalism (a prisoner's dilemma of the inevitability of conflict) seems a bleak reflection of formative experience within China's authoritarian regime in the 1960s and 1970s. ${ }^{17}$

DVP: Yes, I loved that trilogy and, like you, thought the application of game theory to galactic sociology absolutely brilliant. At the same time, I thought it actually worse than bleak. I found it horrifying. And actually unbelievable. I guess I have a strong faith in long-term moral progress. I just cannot believe that truly advanced civilizations would be as immorally self-serving as Liu portrays them. Of course, I am talking of a long-term development.

JM: Again, Rescher has much to say regarding that and 'rational' learning and in Critical Realist circles, Heikki Patomäki, the Finnish global political economist says similar things regarding civilizational learning, albeit more systematically, connecting mythmaking and cultural learning (he has, for example, an interest in H. G. Wells as

${ }^{16}$ Note from Jamie: in general see also Carrigan et al (2020) and note Doug had an academic interest in some of the main futurists and the issues prior to the Future of the Human Series and in addition to it (see Porpora 2000b, 2013a, 2018).

${ }^{17}$ Note from Jamie: political realism should not be confused with philosophical realism; it is a tradition in international relations (IR) theory focused on balance of power between states, and the problem of anarchy (a Hobbesian state of nature problem). In IR theory this is closely associated with the work of Hans Morgenthau and Kenneth Waltz. 
both a writer of fiction and as a futurist). Heikki is a realist and optimistic regarding human potential - and is one of many who write about 'concrete utopias'. Sometimes, of course, it is more difficult to be optimistic than others. Events over the last decade seem to have unfolded according to a logic of worse cases.

DVP: For the moment, in my country especially, we are gripped by an outbreak of what I consider actual evil.

JM: A term whose language use rings oddly to the secular ear.

DVP: It does, I agree, but it also seems appropriate. In my country as elsewhere, we see a populist turn opposed to expertise, knowledge work, and cosmopolitanism. In itself, I would not call that tendency evil. It becomes evil, I think, when it denies all that Al Gore called 'inconvenient truths' - truths contrary to narrow, immediate interests of the 'tribe'. Such stance involves more than the denial of climate change, which is bad enough, but also includes racism, xenophobia, and a degree of selfishness that I do consider evil. I could go on and on about this current pass, but I cannot believe it is more than a counterblip in history that all people of good will should do all in their power to oppose.

JM: Perhaps it is a 'blip', though surely this is highly conditional, many factors have contributed to Trump's place in the world, a point that returns us to your work on religion. Whilst you have previously pointed out that the 'secular media' has resisted moral positions, it is also the case that in the USA the religious right have taken contradictory positions from an ethical standpoint.

DVP: The data suggest that the divide in America ${ }_{2}$ even more than between the college and non-college educated, is race and religion. As Thomas Edsall (2020) reports in the New York Times, in the United States, if you are white and Christian, you vote for Trump and the Republicans. To me, this is a scandal, an indictment of what Christianity has become in America. It makes me ashamed to call myself Christian. In this connection, though, I often find myself saying to people, you can be a Mike Pence type Christian or a Pete Buttigieg Christian. The conservative Christianity of Vice-President Mike Pence is simplistically faithful to the literal and inerrant word of the Bible, regardless of effects on people. I consider the Bible, like the Qur'an or the Upanishads or the Talmud, a socio-historically developing reaction to the divine, but not the word of the divine itself. My faith stands with the gay Christian, Pete Buttigieg, married to his partner, that seeks not personal salvation in an afterlife but the rule of love and justice on Earth - in the language of religion, the establishment of 'God's reign', or, since you referred to Marx earlier, the spirit of communism, if you want to call it such. Conservative Christianity in contrast has sold its soul to Donald Trump's racism.

JM: Trump seems an exceptional figure in many ways. He systematically violates every norm associated with the position of US President (see Gills et al 2019) and that begins with his relation to truth. It is not that we expect real President's to conform to the fictional archetype (no matter how many times Morgan Freeman plays the role), but being seen to lie or be reckless of truth, previously mattered - 'truth seeming' was part of Presidential performance, and adherence to this has been one strand of the checks and balances that have surrounded a President (and arguably any public office in a democracy, from a Habermasian perspective, contrasting the grounds of 'legitimation crisis' and those of viable 'Communicative action').

DVP: I think it important to say that no Critical Realist would try to make sense of Trump in the absence of context. Trump is a symptom. My IACR presidential address, 'Populism, Citizenship, and Post-Truth Politics', presented at the 2019 meetings in Southampton is an analysis of this situation. It will be coming out in Journal of Critical Realism.

Formatted: Font color: Auto

Formatted: Font: Not Bold

Formatted: Font: Not Italic 
JM: It is not obvious, however, that Trump as President makes any sense if you begin from the standard criteria of competence and good faith: knowing what you mean and meaning what you say. Despite some of the dubious history of American Presidents, there still seems some distance from the America that is written about in How Holocausts Happen (Porpora 1990) to the one we now find ourselves in. Trump's exceptionalism though, must surely be a matter of structural and cultural processes?

DVP: There are factors specific to America, like the realignment of the two parties. After Nixon's so-called 'Southern Strategy' won over to the Republican party the racist Dixiecrats, the Republican party much more than the Democratic had an atavistic, racist wing that also coincided with a kind of parochial, less educated Christianity. For decades now, Republicans have employed more implicit dog whistles to mobilise this base. This has evolved with dog whistles becoming now more blatant in the case of Trump.

JM: So Trump is, in a sense, a consequence of the kind of things you were thinking about when writing How Holocausts Happen, and Post-Ethical Society (Porpora et al 2013) if only in some ways indirectly?

DVP: Yes, even in How Holocausts Happen, I was concerned with the way populations - particularly my own - seek to insulate themselves from painful truths. But regarding Trump, in addition to factors idiosyncratic to America, there is also something more systemic that is going on, and that, I think, is a populist counter-reaction to globalization and cosmopolitanism. In the IACR talk I mentioned, I refer to Benjamin Barber's Jihad vs. McWorld (Barber 2003 [1995]). He spoke of future tension between globalized capitalism and parochial traditionalism. He expected this conflict to erupt in force in the less developed world, and there are eruptions there as we know. What was less expected was to have such 'Jihad' erupt so forcibly in the countries of the socalled international core.

JM: A loaded term, easily misconstrued, but quite flexible when used metaphorically to refer to a whole host of problems and issues, many of which have nothing immediately to do with race or religion, although these become dividing lines and clarion calls - in the US case, a kind of fearful revisionist nostalgia tied to a strangely punitive optimism. This is also something that Heikki Patomäki has interesting things to say about (Patomäki 2017), though he is not alone and has more in mind that just democracies. There is also a lot of work now in political theory on 'how democracies die'. Recent thinking on this seems to have shifted from Charles Taylor's thesis that democracy will likely descend quietly into soft paternal technocratic authoritarianism. Runciman (2018), for example, argues that if one looks to the range of democracies, including those we have considered most enduring and stable, it doesn't make sense to assume that 'democracies' can only be destroyed by military coups. At the same time, Taylor's version of the future of democracy from thirty years ago seems a little too benign and passive. The world today seems rife with systemic tensions and arising conflicts of ideas and interests (see also Levitsky and Ziblatt 2018).

DVP: The eruption is, in my opinion, a populist class war against knowledge work and knowledge workers.

JM: And this is something you have done recent work on in essays such as 'Truth, communication and democracy,' (Porpora and Sekalala 2019) and 'Entertainment politics as a Modernist project in a Baudrillard world' (Richmond and Porpora 2019)?

DVP: Partly. It seemed important to do this work because truth itself and its determination is no longer just an academic issue but very much political.

JM: As your Baudrillard essay indicates, it seems, for example, ironic that we now look to comedians to speak truth, counter 'post-truth' and speak truth to power. Figures like John Oliver and Trevor Noah are fulfilling a function that social science seems to have partly vacated. Would you suggest any of this has context in terms of 
'the culture wars' (something we suggested earlier we might return to in relation to post-structuralism)?

DVP: I would say, as most Critical Realists would, that postmodernist post-structuralism not only offers no help here, but actually has served to justify the conservative tribal relativism against which we now contend.

JM: This seems an obvious inference from, for example, Andrew Sayer's essay collection, Realism and Social Science (Sayer 2000). Realism was written at perhaps the time of greatest influence of post-modernism on social science (see especially Chapter 3 on 'Pomo Flips') and reads as an excellent companion to your own later Reconstructing Sociology.

DVP: Yes. It may have seemed great fun when the liberal left was at ironic play with truth and reality. It is much less fun now that the right is playing the same game.

JM: Legacy and long term processes are obviously important, but in an immediate sense it seems figures like Alex Jones or Jordan Peterson are more significant in popular terms (and amusing cuts both ways, since the Alan Sokal 'prank' of 1996 or the more recent attempt to expose, burst or satirise contemporary versions of postmodern relativism and academic integrity by James Lindsay, Helen Pluckrose, and Peter Boghossian can equally seem trivial in their consequences). Trump, as you say is as much a symptom as cause, and would be considerably less worrying if the checks and balances in the US system were operational (if they were, of course, it seems arguable that the Republicans would ever have selected him in the first place - again an issue that cuts both ways - how to prevent elitism in selection processes without the opening-up leading to other problems -as Bernie Sanders found in 2015-16). The popular public intellectual Malcolm Gladwell's latest book Talking to Strangers makes the point that our species is primed to want what people say to be true and this leads to the problem of exploitation, if and when institutions cease to operate effectively. Our 'trusting nature' becomes a weapon that can be used against us. Gladwell's books are typically simplistic, but the underlying point does seem to speak to some of our contemporary dilemmas. Trump, for example, seems a particularly unfortunate occupant of the White House at a time of real crisis such as Covid-19.

DVP Well, if we go back to the previously mentioned book on realism by Sayer (2000), Andrew calls for an ethical turn in the social sciences to which Critical Realists have now largely responded. In my forthcoming populism article in Journal of Critical Realism — and also my recent article on morality ( Porpora 2019c), I call for an extension of this concern to the ethics of belief. What we believe or allow ourselves to believe, or what we refuse to believe despite the evidence are all an ethical matter. I describe a commitment to truth, however inconvenient or contrary to the tribe it turns out to be, as a value basic to deliberative democracy. As final comment on this subject and in this interview, I think the times make Critical Realism more relevant and more important than ever. Democracies 'die' if we let them and we now have a situation where democracy is in jeopardy, while American lives are being lost on a scale greater than the Vietnam war because the American right slavishly follows an imbecilic president in discounting even our top physicians. So, the importance of Critical Realism's own steadfast commitment to truth and its determination clearly extends beyond the Academy.

\section{Notes on Contributors}

Douglas V. Porpora is Professor of Sociology, Department of Communication, Drexel University, Philadelphia. $\mathrm{He}$ is co-editor of Journal for the Theory of Social Behaviour and author of numerous books and articles. Additional detail is given in the interview.

Jamie Morgan is Professor of Economic Sociology at Leeds Beckett University. He co-edits the Real-World Economics Review with Edward Fullbrook. He has published widely in the fields of economics, political 
economy, philosophy, sociology and international politics.

\section{References}

Archer, M.S. Bhaskar, R. Collier, A. Porpora, D. V. Lawson, T. and Norrie, A. 1998. Critical Realism: Essential Readings. London: Routledge.

Archer, M. S. Collier, A. and Porpora, D. V. 2004. Transcendence: Critical Realism About God. London: Routledge.

Archer, M. S. and Elder-Vass, D. 2012. "Cultural system or norm circles? An exchange.” European Journal of Social Theory 15: $93-115$.

Archer, M. S. and Morgan, J. 2020. "Contributions to realist social theory: an interview with Margaret S. Archer.” Journal of Critical Realism 19 (2): 179-200.

Ayer, A. J. 1983. Language, Truth and Logic. London: Pelican.

Barber, B. 2003 [1995]. Jihad vs McWorld. London: Corgi.

Bhaskar, R. 1979 [2008]. A Realist Theory of Science. London: Verso.

Bhaskar, R. 1989. Reclaiming Reality. London: Verso.

Bhaskar, R. 1993. Dialectic: The Pulse of Freedom. London: Verso.

Bhaskar, R. 1994. Plato Etc. London: Verso.

Bhaskar, R. 2014. The Possibility of Naturalism. London: Routledge, $4^{\text {th }}$ edition.

Carrigan, M. Porpora, D. V. and Wight, C. 2020. Post-Human Futures. London: Routledge [The Future of the Human Series, Volume III].

Colledge, B. Morgan, J. and Tench, R. 2014. "The Concept of Trust in Late Modernity, the Relevance of Realist Social Theory." Journal for the Theory of Social Behaviour 44 (4): 481-503.

Collier, A. 1990. Socialist Reasoning. London: Pluto Press.

Collier, A. 1994. Critical Realism. London: Verso.

Collier, A. 2005. Being and Worth. London: Routledge.

Edsall, T. 2020. "In God we divide." New York Times March $25^{\text {th }}$

Elder-Vass, D. 2007a. "For Emergence: Refining Archer's Account of Social Structure.” Journal for the Theory of Social Behaviour 37 (1): 25-44.

Elder-Vass, D. 2007b. "Social Structure and Social Relations." Journal for the Theory of Social Behaviour 37 (4): $463-477$.

Danermark, B. Ekstrom, M. Jakobsen, L. and Karlsson, J. 2019. Explaining Society: An introduction to critical realism in the social sciences London: Routledge, second edition.

Gills, B. Morgan, J. and Patomäki, H. 2019. "President Trump as status dysfunction.” Organization 26 (2): 291-301.

Groff, R. 2004. Critical Realism, Post-Positivism and the Possibility of Knowledge London: Routledge.

Gorski, P. 2013. "What is Critical Realism? And why should you care?" Contemporary Sociology 42 (5): 658-670.

Hartwig, M. and Morgan, J. 2014. Critical Realism and Spirituality. London: Routledge.

Hume, D. 1962. A Treatise of Human Nature, Volume II. London: Dent.

Jenkins, A. Nikolaev, A. and Porpora, D.V. 2012. "Moral Reasoning and the Online Debate about Iraq." Political Communication 29 (1): 44-63.

Keats, R. and Urry, J. 1975. Social Theory as Science London: Routledge and Kegan Paul

Larson, M. and Porpora, D. V. 2011. "The Resistible Rise of Sarah Palin.” in Sociological Forum 26 (4): 754-778.

Lau, R. and Morgan, J. 2014. "Integrating Discourse, Construction and Objectivity: A Contemporary Realist Approach." Sociology 48(3): 573-589.

Levitsky, S. and Ziblatt, D. 2018. How Democracies Die. New York: Crown.

Lieber, J. 1997. "Comments on Dr. Douglas Porpora's “The Caterpillar's Question: Contesting Anti-Human's Questions.” Journal for the Theory of Social Behaviour 27 (2-3): 363-367.

Lawson, T. 2016a. "Comparing conceptions of social ontology: Emergent social entities and/or institutional facts?" Journal for the Theory of Social Behaviour 46 (4): 359-399.

Lawson, T. 2016b. "Ontology and social relations: Reply to Doug Porpora and to Colin Wight." Journal for the Theory of Social Behaviour 46 (4): 438-449.

Lukes, S. (1974) Power: A radical view Basingstoke: Macmillan

Mitman, T. Nikolaev, A. and Porpora, D. V. 2012. "The Critical Moral Voice on U.S. Newspaper Opinion Pages." Communication, Culture, and Critique 5 (3): 392-408.

Morgan, J. 2005. "Ought and is and the philosophy of global concerns." Journal of Critical Realism 4 (1): 186-210.

Morgan, J. 2007. "Power.” 772-373 in Hartwig, M. (ed.) Dictionary of Critical Realism. London: Routledge. 
Morgan, J. 2014. "What is progress in realism? An issue illustrated using norm circles." Journal of Critical Realism 13(2): $115-138$

Morgan, J. 2015. "Realists divided by realism? Wright on Triune Christianity.” Journal of Critical Realism 14 (4): $397-$ 415.

Morgan, J. 2016. "Change and a changing world? Theorizing Morphogenic society." Journal of Critical Realism 15 (3): 277-295.

Morgan, J. 2019a. "Will we work in twenty-first century capitalism?' A critique of the fourth industrial revolution literature." Economy and Society 48 (3): 371-398.

Morgan, J. 2019b. "Why is there anything at all? What does it mean to be a person? Rescher on metaphysics." Journal of Critical Realism 18 (2): 169-188.

Norris, C. 1991. Deconstruction: Theory and Practice. London: Routledge, revised edition.

Olsen, W. 2019. "Social statistics using strategic structuralism and pluralism." Chapter 8, 237-262 in Nagatsu, M and Ruzzene, A. (eds) Contemporary Philosophy and Social Science: An interdisciplinary dialogue. London: Bloomsbury.

Olsen W. 2012. Data Collection. London: Sage.

Olsen, W. and Morgan, J. 2005. "A critical epistemology of analytical statistics: Addressing the skeptical realist." Journal for the Theory of Social Behaviour 35 (3): 255-284.

Patomäki, H. 2017.Disintegrative Tendencies in the Global Political Economy. London: Routledge.

Porpora, D. V. 1980. "Operant Conditioning and Teleology." Philosophy of Science 47 (4): 568-582.

Porpora, D. V. 1982. "Nonreductive Materialism and the Materialisms of Marx and Heidegger." Human Studies 5:13-30.

Porpora, D. V. 1983a. "On the Post-Wittgensteinian Critique of the Concept of Action in Sociology." Journal for the Theory of Social Behaviour 13 (2): 129-146.

Porpora, D. V. 1983b. "On the Prospects for A Nomothetic Theory of Social Structure." Journal for the Theory of Social Behaviour 13 (3): 243-264.

Porpora, D. V. 1983c. "Rejoinder.” Journal for the Theory of Social Behaviour 13 (3): 309-329.

Porpora, D.V. 1987. The Concept of Social Structure. Westport, CT: Greenwood Press.

Porpora, D. V. 1989a. “A Response to Turner's Behavioral Theory of Social Structure.” Journal for the Theory of Social Behaviour 19 (1): 127-130.

Porpora, D. V. 1989b. "Four concepts of social structure." Journal for the Theory of Social Behaviour 19 (2): 195-211

Porpora, D. V. 1990. How Holocausts Happen: The United States in Central America. Philadelphia: Temple University.

Porpora, D.V. 1993. "Cultural Rules and Material Relations." Sociological Theory 11 (2): 212-229.

Porpora, D. V. 1997. “The Caterpillar's Question: Contesting Anti-Humanism's Contestations.” Journal for the Theory of Social Behaviour 27 (2-3): 243-263.

Porpora, D. V. 2000a. "The sociology of ultimate concern.” Alethia 3 (1): 10-15.

Porpora, D. V. 2000b. "Quantum Reality as Unrealised Possibility." Alethia 3 (2): 34-39.

Porpora, D. V. 2001a. Landscapes of the Soul: The Loss of Moral Meaning in American Life. New York: Oxford University Press.

Porpora, D. V. 2001b. "Do Realists run regressions?" In After Postmodernism: An Introduction to Critical Realism, edited by José López and Gary Potter, 260-268. London: Athlone.

Porpora, D. V. 2004. "Objectivity and phallogogentricism." In Defending Objectivity: Essays in Honour of Andrew Collier, edited by Margaret Archer and William Outhwaite, 48-59. London: Routledge.

Porpora, D.V. 2005. “Agency and Action. Edited by John Hyman and Helen Steward.” Journal of Critical Realism 4 (2): 483-487.

Porpora, D. V. 2006. "Methodological Atheism, Methodological Agnosticism and Religious Experience.” Journal for the Theory of Social Behaviour 36 (1): 57-75.

Porpora, D. V. 2007a. “On Elder-Vass: Refining a Refinement.” Journal for the Theory of Social Behaviour 37 (2): $195-$ 200.

Porpora, D. V. 2007b. “Agents, Structures and International Relations: Politics as Ontology. By Colin Wight.” Journal of Critical Realism 6 (2): 305-312.

Porpora, D. V. 2009. "Contributions to Social Ontology. Edited by Clive Lawson, John Latsis, and Nuno Martins." Journal of Critical Realism 8 (1): 124-128.

Porpora, D. V. 2011. "Critical Terrorism Studies: A Political Economic Approach Grounded in Critical Realism." Critical Studies on Terrorism 4 (1): 39-56.

Porpora, D. V. 2013a. "How Many Thoughts Are There? Or Why We Likely Have No Tegmark Duplicates $1010^{\wedge} 115$ meters Away." Philosophical Studies 163:133-149. 
Porpora, D. V. 2013b. "Morphogenesis and social change.” In Social Morphogenesis, edited by Margaret Archer, 25-38. Dordrecht: Springer [Social Morphogenesis Series, Volume I].

Porpora, D. V. 2014. “Contemporary mechanisms of social change.” In Late Modernity: Trajectories Towards Morphogenic Society, edited by Margaret Archer, 77-92. Dordrecht: Springer [Social Morphogenesis Series, Volume II].

Porpora, D. V. 2015. "Why things don't change? The matter of Morphostasis." In Generative Mechanisms Transforming the Social Order, edited by Margaret Archer, 185-204. Dordrecht: Springer [Social Morphogenesis Series, Volume III].

Porpora, D. V. 2016a. "The great normative changes of the twentieth century." In Morphogenesis and the Crisis of Normativity, edited by Margaret Archer, 31-47. Dordrecht: Springer [Social Morphogenesis Series, Volume IV]

Porpora, D. V. 2016b. “The Relational Subject.” Journal of Critical Realism 15 (4): 419-425.

Porpora, D. V. 2016c. "The Recent Methods Debate in American Sociology and how Critical Realism fits into it." Journal of Critical Realism 15 (4): 342-351.

Porpora, D. V. 2016d. "Response to Tony Lawson: Sociology versus economics and philosophy." Journal for the Theory of Social Behaviour 46 (4): 420-425.

Porpora, D. V. 2016e. Reconstructing Sociology: The Critical Realist Approach Cambridge: Cambridge University Press

Porpora, D. V. 2017a. "Some Reservations About Flourishing." In Morphogenesis and Human Flourishing, edited by Margaret Archer, 45-62. Dordrecht: Springer [Social Morphogenesis Series, Volume V].

Porpora, D. V. 2017b. "Dehumanization in theory: anti-humanism, non-humanism, post-humanism, and trans-humanism" Journal of Critical Realism 16 (4): 353-367.

Porpora, D. V. 2017c. "Tony Lawson from a sociological point of view." Cambridge Journal of Economics 41 (5): $1525-$ 1537.

Porpora, D. V. 2018. "Materialism, emergentism, and social structure: A response to Wendt's Quantum Mind.” Journal for the Theory of Social Behaviour 48 (2): 183-187.

Porpora, D.V. 2019a. Vulcans, Klingons and humans: What does humanism encompass?" In Realist Responses to PostHuman Society: Ex Machina, edited by Ismael Al-Amoudi and Jamie Morgan, 33-52. London: Routledge [The Future of the Human Series, Volume I].

Porpora, D. V. 2019b. "What they are saying about artificial intelligence and human enhancement." In Post-Human Institutions and Organizations: Confronting the Matrix, edited by Ismael Al-Amoudi and Emmanuel Lazega, 1427. London: Routledge [The Future of the Human Series, Volume II]

Porpora, D. V. 2019c. "A reflection on critical realism and ethics." Journal of Critical Realism 18 (3): 274-284.

Porpora, D.V., Lim, M. H, and Prommas, U. 1989. "The role of women in the international division of labour: The case of Thailand." Development and Change 20 (2): 269-294.

Porpora, D.V., Lim, M. H, and Prommas, U. 1992. "Rejoinder to Narayanan and Kimura." Development and Change 23 (2): $149-153$.

Porpora, D. V. and Nikolaev, A. 2007. "Talking War: How Elite U.S. Newspaper Editorials and Opinion Pieces Debated the Attack on Iraq." Sociological Focus. 40 (1): 6-25, 2007.

Porpora, D. V., Nikolaev, A. and Hagemann, J. 2010 “Torture, Abuse, Frames, and the Washington Post." Journal of Communication 60(2): 254-270.

Porpora, D. V. Nikolaev, A. Hagemann, J. and Jenkins, A. 2013. Post-Ethical Society: The Iraq War, Abu Ghraib, and the Moral Failure of the Secular. Chicago: University of Chicago Press.

Porpora, D.V. and Sekalala, S. 2019. “Truth, communication and democracy.” International Journal of Communication 13: 938-955.

Rescher, N. and Morgan, J. 2020. "Philosophical purpose and purposive philosophy: An interview with Nicholas Rescher." Journal of Critical Realism 19 (1): 58-77.

Richmond, J. and Porpora, D.V. 2019. "Entertainment politics as a Modernist project in a Baudrillard world." Communication Theory 29 (4):421-440.

Runciman, D. 2018. How Democracy Ends. London: Basic Books.

Sayer, A. 1992. Method in Social Science. London: Routledge, second edition.

Sayer, A. 2000.Realism and Social Science. London: Sage.

Searle, J. 1964. "How to derive 'ought' from 'is'.” The Philosophical Review 73 (1): 43-58.

Smith, C. 2016. To Flourish or Destruct? Chicago: Chicago University Press.

Turner, J. 1983. "Idiographic vs. Nomothetic Explanation: A Comment on Porpora's Conclusion." Journal for the Theory of Social Behaviour 13 (3): 273-280. 